\title{
MODEL LASSWELL DALAM KOMUNIKASI PEMBANGUNAN KAWASAN WISATA BENGKULU
}

\author{
Oleh:
}

\section{LINDA ASTUTI, KHAIRIL BULDANI}

Dosen Prodi Ilmu Komunikasi FISIP Universitas Ratu Samban Bengkulu Utara, Dosen Prodi Ilmu Komunikasi FISIP Universitas Bengkulu

\begin{abstract}
As a consequence of the optimization resources area policy, tourism was becoming one of the favored sectors. Development of the tourism sector could run well with good communication between the Government and society, so communication was considered important in the development process. Therefore, it was necessary to develop a communication strategy so that messages could be received well. The purpose of this study was to determine the communication strategy development undertaken by the Department of Culture and Tourism of Bengkulu province in tourism development by using analytical tools Lasswel components. Research results showed that the Department of Culture and Tourism has been communicated by applying the Lasswell model.
\end{abstract}

\section{Keywords: Model Lasswell, Development Communication, Tourism Area, Bengkulu}

\section{PENDAHULUAN}

Sebagai daerah yang mempunyai potensi pariwisata, kota Bengkulu berupaya melakukan pengembangan di bidang Pariwisata sebagai wujud dari pemanfaatan potensi daerah. Keindahan alam dan nilai sejarah merupakan faktor pendukung utama dalam pengembangan pariwisata di kota Bengkulu. Daya tarik dari keindahan alam tersebut ialah Pantai Panjang yang indah dan berbagai situs peninggalan sejarah seperti Benteng Marlborough.

Pemerintah daerah menyadari potensi yang ada, bahwa dalam rangka percepatan pembangunan daerah, salah satu sektor yang menjadi andalan untuk memperoleh pendapatan asli daerah adalah sektor wisata. Pariwisata daerah perlu mendapat perhatian lebih mendalam khususnya aset-aset wisata yang memiliki potensi wisata yang bukan saja bernilai historis melainkan aset wisata yang berpotensi ekonomis. Dalam memacu pertumbuhan ekonomi dan peningkatan kesempatan kerja, maka industri pariwisata dijadikan salah satu sektor andalan, dimana pariwisata dianggap sebagai salah satu industri yang menimbulkan efek ganda bagi sektor lainnya. Dalam pengembangan potensi pariwisata harus dilakukan sesuai dengan strategi pengembangan agar objek wisata tersebut dapat dimanfaatkan bagi peningkatan perekonomian masyarakat sekitar. Untuk itu, Dinas Kebudayaan dan Pariwisata Provinsi Bengkulu mewacanakan pembangunan Kawasan Wisata di Bengkulu berupa upaya memadukan berbagai jenis wisata yang ada dengan membangun berbagai fasilitas penunjang seperti Museum Purbakala, kolam renang, wahana bermain, waterpark dan hotel sebagai tempat menginap wisatawan yang berkunjung.

Menurut pendapat Oka A. Yoeti dalam bukunya Pemasaran Pariwisata menyatakan daerah tujuan wisata (tourism destinations) harus memiliki empat komponen yakni: 
1) Daya tarik (tourism attractions)

2) Akses transportasi mudah dijangkau

3) Fasilitas (restoran, akomodasi, tempat hiburan, mandi cuci kakus)

4) Ancillary service, yaitu organisasi kepariwisataan yang dibutuhkan dalam pelayanan wisatawan seperti tenaga pariwisata (guide, PHRI, tour and travel transport agent, dsb).

Pengembangan pariwisata pada dasarnya adalah pengembangan masyarakat, wilayah, dan selanjutnya perlu didasarkan pada kriteria sebagai berikut:

1) Memajukan tingkat hidup masyarakat sekaligus melestarikan identitas budaya dan tradisi lokal.

2) Meningkatkan tingkat pendapatan secara ekonomis sekaligus mendistribusikan secara merata pada penduduk lokal.

3) Berorientasi pada pengembangan wiraswasta berskala kecil dan menengah dengan daya serap tenaga kerja tinggi dan berorientasi pada teknologi kooperatif.

4) Memanfaatkan pariwisata seoptimal mungkin sebagai agen penyumbang tradisi budaya dengan dampak negatif seminim mungkin.

Dalam pengembangan kepariwisataan, sarana pendukung perlu mendapat perhatian baik dari segi fasilitas umum juga pemberdayaan masyarakat sekitarnya. Dengan melibatkan partisipasi masyarakat sejak awal, maka akan lebih terjamin kesesuaian program pengembangan dengan aspirasi masyarakat setempat. Menurut pedoman pengembangan kawasan pariwisata yang dikeluarkan oleh Direktorat Jenderal Pariwisata, pengembangan pariwisata apabila ditinjau dari pengelolalannya serta hubungan antara usaha pariwisata yang berlokasi dalam suatu wilayah dibagi dalam:

1) Pariwisata terpadu/terintegrasi yaitu badan usaha yang mengelola secara bersama dan saling menunjang sarana pariwisata didalam suatu wilayah dan yang telah ditetapkan sebagai pusat kunjungan.

2) Pariwisata tunggal/terkonsentrasi yaitu sistem pengelolaan bentangan alam yang mempunyai batas dan luas tertentu, memiliki potensi wisata alam atau sosial-budaya, menjadi objek wisata yang dipersiapkan sebagai tempat hiburan dengan berbagai fasilitas pemukiman dan fasilitas lainnya bagi wisatawan oleh suatu perusahaan atau badan usaha (JIKP, 2003: 82).

Pelaksanaan pengembangan suatu objek wisata tentunya berdampak pada lingkungan sekitar, sehingga jika berjalan dengan baik maka dengan banyaknya pengunjung akan membuka peluang usaha seperti industri cindera mata, rumah makan, akomodasi, transportasi, pelayanan keamanan, dan kebersihan, sehingga dapat menjadi komoditi bisnis yang tentunya dapat meningkatkan ekonomi rakyat. Pemerintah daerah sebagai fasilitator turut mendukung dengan kebijakan melalui deregulasi atau peraturan daerah yang dapat mengakomodasi industri wisata goa Putri ini. Namun demikian, jika dalam pelaksanaannya tidak melibatkan warga setempat, berkemungkinan menimbulkan konflik yang berawal dari keresahan warga seiring dengan pembangunan berbagai fasilitas, sarana prasarana yang mengundang banyak pengunjung dan dikhawatirkan mengikis budaya setempat. Tentunya ilmu komunikasi mengambil perannya disini, Dinas kebudayaan dan Pariwisata sebagai komunikator dengan masyarakat sebagai komunikannya. Untuk itu penelitian ini sengaja dibuat untuk mengetahui Pola Komunikasi seperti apa yang dibangun Pemerintah, dalam hal ini Dinas Kebudayaan dan Pariwisata Provinsi Bengkulu dalam upaya pembangunan Kawasan Wisata di Bengkulu. 


\section{METODE PENELITIAN}

Metode penelitian ini menggunakan pendekatan kualitatif. Pendekatan ini lebih bersifat interpretatif subjektif yang artinya individu-indivudu melakukan penekanan terhadap segala prilaku yang terjadi. Bogdan dan Taylor dalam moleong (2001: 1) penelitian kualitatif adalah penelitian yang menghasilkan data deskriptif berupa katakata tertulis atau lisan dari orang-orang dan perilaku yang dapat diamati.

\section{Informan Penelitian}

Informan kunci dalam penelitian ini adalah pihak dinas kebudayaan dan pariwisata provinsi Bengkulu selaku pihak yang bertanggung jawab dalam pengambilan kebijakan.

\section{Teknik Pengumpulan Data}

Metode pengumpulan data yang peneliti lakukan dalam penelitian ini adalah melalui kegiatan observasi langsung, wawancara kepada pihak terkait dan melakukan pengumpulan data yang telah jadi ataupun telah diolah oleh pihak lain serta mengambil dokumentasi yang berkaitan dengan pariwisata

\section{Teknik Analisa Data}

Analisis data dalam penelitian kualitatif dilakukan pada saat pengumpulan data berlangsung, dan setelah selesai pengumpulan data dalam periode tertentu. Selain itu, analisis data berlangsung bersamaan dengan proses pengumpulan data melalui 3 tahapan yang dilakukan secara simultan yaitu reduksi data, penyajian data dan verifikasi data (pengambilan kesimpulan)

\section{HASIL PENELITIAN}

\section{Komunikasi Pembangunan Dinas Kebudayaan dan Pariwisata Provinsi Bengkulu}

Komunikasi pembangunan meliputi peran dan fungsi komunikasi sebagai suatu aktivitas pertukaran pesan secara timbal-balik di antara semua pihak yang terlibat dalam usaha pembangunan, terutama antara masyarakat dengan pemerintah, sejak dari proses perencanaan, pelaksanaan dan penilaian terhadap pembangunan (Nasution, 2006: 34).

Perubahan terjadi sebagai efek dari komunikasi melalui tahap yang dimulai dengan membangkitkan perhatian, menumbuhkan minat yang melahirkan keputusan untuk mengambil tindakan. Dengan menggunakan strategi persuasif dengan tahapan-tahapan yakni perencanaan, pelaksanaan dan evaluasi.

Perencanaan Komunikasi adalah suatu proses pengambilan keputusan atas sejumlah alternatif mengenai sasaran dan cara-cara yang akan dilaksanakan di masa yang akan datang guna mencapai tujuan yang dikehendaki serta pemantauan dan penilaian atas hasil pelaksanaannya yang dilakukan secara sistematis dan berkesinambungan.

Proses perencanaan pembangunan dibutuhkan suatu pendekatan perencanaan yang digunakan sebagai pengambil keputusan serta menunjukkan bagaimana proses perencanaan tersebut dilakukan hingga muncul suatu pengambilan keputusan. Ada dua jenis perencanaan komunikasi, yang pertama perencanaan dengan sistem Top Down Planning artinya adalah perencanaaan yang dilakukan oleh lembaga pemerintahan sebagai pemberi gagasan awal serta pemerintah berperan lebih dominan dalam mengatur jalannya program yang berawal dari perencanaan hingga proses evaluasi, di mana peran masyarakat tdak begitu berpengaruh. Kedua adalah perencanaan dengan sistem Bottom Up Planning artinya adalah perencanaan yang dilakukan di mana masyarakat lebih berperan dalam hal pemberian gagasan awal sampai dengan mengevaluasi program yang telah dilaksanakan sedangkan pemerintah pemerintah hanya sebagai fasilitator dalam suatu jalannya program.

\section{Analisa Model Komunikasi Lasswell}

Strategi komunikasi pembangunan pada kaitannya dalam Model Komunikasi 
Lasswell ialah pihak Disbudpar sebagai source atau sumber pesan, message yang ingin disampaikan adalah provinsi Bengkulu sebagai tujuan wisata baik tingkat nasional maupun internasional, When, pesan disampaikan pada saat eventevent, pameran di dalam maupun di luar provinsi, Where pada saat ada kegiatan dan event Disbudpar, Whom pesan disampaikan kepada wisatawan yang akan berkunjung dan para pelaku usaha perjalanan, dan How membuka website agar mudah diakses, mengadakan sosialisasi ke daerah-daerah lain, menjalin kerjasama dengan media massa dan membuat brosur dan booklet. Analisis komponen-komponen dalam model Lasswell dikaitkan dengan komunikasi dengan Disbudpar Provinsi Bengkulu dalam pembangunan Kawasan Wisata adalah sebagai berikut:

1. Source (Sumber)

Menurut Lasswell, sumber akan mempunyai kredibilitas yang tinggi mana kala ia memiliki keterampilan untuk berkomunikasi secara lisan atau tertulis (communication skills), memiliki pengetahuan yang luas tentang apa yang dibahasnya (knowledge), memiliki sifat yang jujur dan bersahahabat (attitude) serta mampu untuk beradaptasi dngan lingkungan sistem sosial dan budaya (social and cultural system) dimana khalayak berada.

Upaya yang dilakukan pihak Disbudpar untuk membangun kredibilitas antara lain dengan melakukan studi banding kepariwisataan ke daerah-daerah lain, hal ini dilakukan untuk menambah pengetahuan (knowledge) tentang konsep Kawasan Wisata yang nantinya akan diteerapkan di Provinsi Bengkulu.

2. Message (pesan)

Pesan yang dimaksud dalam proses komunikasi ini adalah sesuatu yang disampaikan pengirim kepada penerima. Pesan dapat disampaikan dengan cara tatap muka atau dapat melalui media komunikasi. Isinya bisa berupa ilmu pengetahuan, hiburan, informasi, nasihat dan propaganda. Pesan dalam komunikasi, menurut Lasswell terdapat unsur kontrol dalam pesan tersebut, diantaranya unsur atau elemen, isi, perlakuan dan struktur.

Pesan yang disampaikan pihak Disbudpar Provinsi Bengkulu mengandung alasan yang logis, masuk akal dan menyentuh emosional. Misalkan alasan yang logis dalam pembangunan Kawasan Wisata ini ialah dengan selalu menekankan bahwa tujuan pembangunan. Kawasan Wisata ini ialah untuk kesejahteraan warga setempat. 3. When (kapan pesan akan
disampaikan)

Secara umum pesan akan disampaikan pada saat ada event-event, kegiatan berupa acara festival Tabot, acara ulang tahun kota Bengkulu, hari batik besurek, dan mengadakan pameran yang diikuti oleh semua kabupaten se-provinsi Bengkulu dan kabupaten yang berbatasan dengan provinsi Bengkulu di dalam maupun di luar provinsi dan mengikuti pameran industri kreatif yang disponsori oleh Dewan Kerajinan Nasional dan Departemen Perdagangan dan Perindustrian.

4. Where (dimana pesan disampaikan) Dinas Kebudayaan dan Pariwisata Provinsi Bengkulu dalam strateginya untuk menjadikan provinsi Bengkulu sebagai daerah tujuan wisata baik nasional maupun internasional, melakukan berbagai strategi antara lain dengan mengadakan pameran-pameran di dalam provinsi Bengkulu dan diluar provinsi Bengkulu, melakukan studi banding ke provinsi lain.

5. Whom (kepada siapa pesan
disampaikan)
Informasi kepariwisataan provinsi Bengkulu ditujukan bagi para wisatawan baik lokal maupun mancanegara yang akan berkunjung ke Bengkulu dan dapat memberikan inspirasi bagi para pelaku usaha perjalanan untuk ikut menanamkan modal dalam bisnis kepariwisataan yang dapat meningkatkan daya saing provinsi Bengkulu sebagai daerah tujuan wisata. 
6. How

(bagaimana

pesan

disampaikan)

Dinas Kebudayaan dan Pariwisata

Provinsi Bengkulu terus berupaya meningkatkan wisata yang ada di Bengkulu, guna memuaskan dampak pada pembentukan citra Disbudpar provinsi Bengkulu. Upaya yang dilakukan oleh Disbudpar provinsi Bengkulu dalam rangka meningkatkan minat wisatawan dengan cara:

1. Meningkatkan tempat wisata yang ada di provinsi Bengkulu

2. Memperbaiki fasilitas tempat pelayanan wisata

3. Membuka info agar mudah diakses

4. Mengadakan sosialisasi ke daerah-daerah lain untuk memperkenalkan wisata yang ada di daerah Bengkulu

5. Menjalin kerjasama dengan media massa dalam rangka memperkenalkan wisata-wisata yang ada di kota Bengkulu, melalui media cetak maupun elektronik.

\section{PENUTUP}

\section{Kesimpulan}

1. Strategi yang dilakukan Dinas Kebudayaan dan Pariwisata Provinsi Bengkulu dalam pembangunan wisata antara lain, mengeksplor dan memaksimalkan wisata yang ada di provinsi Bengkulu, memperbaiki fasilitas tempat wisata, membuat website sendiri, mengadakan kunjungan kerja ke provinsi lain, dan mencetak brosur dan booklet tentang semua tujuan wisata yang ada di provinsi Bengkulu.

2. $5 \mathrm{~W}+\mathrm{H}$ (model Lasswell) di terapkan oleh Dinas Kebudayaan dan Pariwisata Provinsi Bengkulu dalam memperkenalkan provinsi Bengkulu sebagai daerah tujuan wisata.

\section{Saran}

1. Kepada Dinas Kebudayaan dan Pariwisata Provinsi Bengkulu diharapkan dapat meningkatkan kualitas pelayanan usaha jasa investasi bidang pariwisata, dapat menciptakan iklim kondusif kepariwisataan lokal, lebih mendorong sumber daya manusia yang ada dalam menangkap peluang sektor pariwisata.

2. Melengkapi fasilitas sarana dan prasarana maupun fasilitas pengunjung lainnya agar wisatawan mendapatkan pelayanan yang baik.

\section{DAFTAR PUSTAKA}

Abdur Razak \& Rimadewi Supriharjo, Pengembangan Kawasan Wisatta Terpadu Di Kepulauan Seribu, Jrnal Teknik POMITS Vol 2. Jurusan Perencanaan Wilayah \& kota, Fakultas Teknik Sipil ITS: Surabaya.

Novi, Mardianto, Junaidi. Evaluasi Pelaksanaan Program Pengembangan Objek Wisata Goa Putri tahun 2011. FISIP, Universitas Sriwijaya, Palembang

Oka A. Yoeti, Pemasaran Pariwisata, 1979, Angkasa: Bandung

Soreno dan Motenson dalam Novi, Mardianto, Junaidi. Evaluasi Pelaksanaan Program Pengembangan Objek Wisata Goa Putri Tahun 2011. FISIP, Universitas Sriwijaya, Palembang.

Sugiono, Prof, DR : metode Penelitian kuantitaf, kualitatif, dan kombinasi, 2012, Alpabet: Bandung

Sumber Lain :

Peraturan Gubernur Bengkulu Nomor : 127 Tahun $2000 \quad$ Tentang Organisasi dan Tata Kerja Dinas Kebudayaan dan Pariwisata Provinsi Bengkulu. 
Jurnal Professional FIS UNIVED Vol. 3 No. 3 Desember 2016

Peraturan Gubernur Bengkulu Nomor 19 Tahun 2008 Tentang Tugas Pokok Dinas Kebudayaan dan Pariwisata Provinsi Bengkulu.
Renstra Kementrian Kebudayaan dan Pariwisata Tahun 2009-2013

Undang-undang RI No.10 Tahun 2009 tentang Kepariwisataan. 